\title{
The Effect of Problem Based Learning Combined with Jigsaw Settings towards the Independent Learning of Integrated Social Science
}

\author{
Risma Dwi Arisona ${ }^{1}$, Fenty Indriani ${ }^{2}$, Nastiti Mufidah ${ }^{3}$, Dwi Putri Ayuningtyas ${ }^{4}$ \\ Institut Agama Islam Negeri Ponorogo $0^{1,2,3,4}$ \\ \{arisona@iainponorogo.ac.id ${ }^{1}$, fentyandriani@iainponorogo.ac.id ${ }^{2}$, nastiti@iainponorogo.ac.id ${ }^{3}$, \\ ayuningtyasdwiputri264@gmail.com ${ }^{4}$ g
}

\begin{abstract}
This research is aimed to know the effect of problem based learning modelcombined with jigsaw settings towards theindependentlearning of integrated social science in junior high school. This research applied quasiexperimental design with a non-control group research design. The population of this research was 182 students of SMP N 1 Bandar Pacitan in 2019/2020 Academic Year. There were 56 students used as the samples which were divided into Class VII E as an experimental class and class VII A as a control class. The data was collected by using observation, documentation and independence questionnaire using a Likert scale. The data was analyzed by using t-test with the SPSS program for windows 2018. Based on the results of the $\mathrm{t}$-test analysis, the value ( $\mathrm{sig})=0,000$. This means that $0,000<0.05$, then $\mathrm{H} 0$ is rejected and $\mathrm{H} 1$ is accepted. Then, it can be concluded that there is a significant effect of problem-based learning with jigsaw setting on the independent learning of Integrated Social Studies of junior high school students. In addition, it can also be seen from the average percentage of students' independence that the experimental class is $72 \%$ higher than the control class which is only $60 \%$.
\end{abstract}

Keywords: Problem Based Learning; Jigsaw; Independent learning of integrated social sciences

\section{Introduction}

Independent learning is one of the learning activities that is encouraged by will, choice, and a sense of self-responsibility. Independent learning is a person's thoughts and motives in determining direction, plans, references, and decisions in learning activities. In this case, the students have their own will, choice and a sense of responsibility from learning without depending on others [1]. Independent learning is a form of action that has received little attention in education field, especially in formal education. Students are only led to study together and understand the content of the learning material. As a result, students will only learn when it is required, not on their own accord.

According to Hargis and Kerlin [2], independent learning is a process of planning and controlling oneself towards completing academic assignments independently. Students who 
have high learning independence have the ability to monitor, evaluate, regulate the learning process effectively and efficiently in completing their academic assignments. In line with Hargis and Kerlin's opinion, Suhendri and Mardalena (2015) [3] stated that independent learning is defined as a learning process to achieve the learning objectives, as students are required to be active not dependent on their teachers. Basically independence is the behavior of individuals who are able to take initiative, be able to overcome obstacles / problems, have self-confidence and can do something on their own without the help of others [4].

The indicators of learning independence according to Sumarmo (Purwasih, 2016)[5] are: (1) taking the initiative to learn with or without the help of others; (2) diagnose his own learning needs; (3) formulate / select learning goals / targets; (4) selecting and using sources; (5) selecting learning strategies, and evaluating learning outcomes; (6) cooperate with other people; (7) construct meaning; and (8) self-control. The regulation of the Minister of Education and Culture Number 68 Regarding the basic framework and curriculum structure in Junior High Schools / Madrasah Tsanawiyah[6]explains that the learning process must be directed at developing student learning independence. Independent learning does not come naturally as it must be accustomed to learning. Therefore, it is necessary to apply innovative learning models in schools in order to foster students' independent learning abilities.

One of the innovative learning models, such as problem-based learning with a jigsaw setting, is expected to foster learning independence. The use of problem-based learning with this jigsaw setting can motivate students to solve such problems that they can provide solutions to these problems. In addition, this learning can create learning situations and conditions that are indispensable in fostering student independence in learning. According to Jhon Dewey [7] problem-based learning is the interaction between stimulus and response, a relationship between two directions of learning and the environment. Students' experiences obtained from the environment will give them materials in order to gain understanding and can be used as learning guidelines and objectives. Problem-based learning is a problemcentered learning activity. The term 'centered' means to be the theme, unit, or content as the main focus of learning.

The use of problem-based learning basically aims to help students develop thinking skills and problem solving skills, learn the role of authentic adults, and become independent learners [8]. In addition, problem-based learning also serves as a material for testing and assessing student competencies, so that teachers do not only use conventional written exams. Problembased learning is able to make students think more optimally through systematic team work so that students can empower, hone, test and develop their thinking skills on an ongoing basis. Deeply, the advantages of problem-based learning are as follows: (1) Realistic with students' lives, (2) concepts according to student interests, (3) fostering the nature of student inquiry, (4) strong retention of concepts, (5) growing problem skills solving [9].

Social Science Subject (Ilmu Pengetahuan Sosial abbreviated as IPS) can be defined as "study of society" in assessing society. Here, teachers can conduct studies from various social perspectives, such as studies of Anthropology, Economics, Geography, Education, Politicalgovernment, aspects of social psychology, history. and sociology which are simplified to achieve learning goals [10]. In general, IPS at junior high school (SMP / MTs) discusses four fields of science, namely economics, history, geography and sociology which are currently known as Integrated IPS.

Complex Integrated IPS material requires such special attentionthat students get used to it independently to be able to understand and solve problems around them. However, the complex material sometimes makes students pay less attention in understanding social studies material, so that students' learning independence is also low. Therefore, habituation of student 
learning independence is the spotlight and attention of social studies educators in the classroom because it is related to the nature and characteristics of social science. Several studies on learning independence. Fahinu (2007) [11],Budiyanto (2014) [12], and Sugandi (2013) [13] found that students who received innovative learning achieved fairly good independent learning. Overall, based on the above description, the authors are interested in conducting research on the effect of problem-based learning with the Jigsaw setting on the Integrated Social Studies of junior high school students' independence learning. This research was conducted on the material of human activities in fulfilling needs..

\section{Research Method}

The approach used in this research is a quantitative approach. The quantitative approach is also called the traditional approach since it has been used for such a long time that it has traditionally been an approach to research [14]. The method used in this research is a quasi experiment. The design used in this study is a non-equivalent group design, which is a design consisting of two classes, an experimental class and a control class. The research design can be seen in the followingtable..

Table1. Research design
\begin{tabular}{cccc}
$\mathrm{O} 1$ & $\mathrm{X}$ & $\mathrm{O} 1$ \\
\hline $\mathrm{O} 2$ & - & $\mathrm{O} 2$ \\
\hline
\end{tabular}

Information:

O1 : Experiment Class

O2 : Control Class

$\mathrm{X}$ : Problem-based learning with a jigsaw cooperative setting

: Questions and answers learning

The research subjects were class VII students of SMP Negeri I Bandar Pacitan even semester of the 2019/2020 academic year who were selected based on the average mid test scores for the Integrated IPS Subject: VII E as the experimental class (83) and VII Aas the control class (84). Each class consists of 28 students. The experimental class was given treatment in the form of problem-based learning with a jigsaw setting, while the control class was given a question and answer model. At the end of the meeting, the two classes were given a learning independence questionnaire to determine the effect on both classes. The learning independence questionnaire consists of 20 questions. The observed aspects of each observation indicator are as follows:

Table 2. Learning Independence Indicators

\begin{tabular}{llll}
\hline $\begin{array}{c}\text { Research } \\
\text { Variable }\end{array}$ & Indicators & & \multicolumn{1}{c}{ The Assessment Aspects } \\
\hline & Confidence & a. & Students learn not to depend on others. \\
& & b. & Students have the courage to act \\
& c. & Students believe in themselves. \\
\cline { 2 - 4 } & Responsibility & a. & Students have self-awareness in learning. \\
& b. & Students do all the assignments given by the teacher well \\
Independent & & c. & Students participate actively and are serious in learning. \\
\cline { 3 - 4 } & & a. & Students learn on their own. \\
\cline { 3 - 4 } & & &
\end{tabular}




\begin{tabular}{lll}
\hline Research & Indicators & \multicolumn{1}{c}{ The Assessment Aspects } \\
\cline { 3 - 3 } & b. & $\begin{array}{l}\text { Students ask and answer without prompting others. } \\
\end{array}$ \\
& c. & $\begin{array}{l}\text { Students try to find other reference sources in learning } \\
\text { without being told by the teacher. }\end{array}$ \\
\cline { 2 - 3 } & a. & Students pay attention to the teacher's explanation during \\
Discipline & lessons. \\
& b. & Students do not postpone assignments \\
& c. & Students are not lazy. \\
\hline
\end{tabular}

Based on the test results, the independent questionnaire instrument is valid and reliable. The results of the questionnaire were used to test the research hypothesis. Then the data were analyzed by using the t-test using the SPSS for windows 2018 program.

\section{Results and Discussion}

Problem-based learning with a jigsaw setting is carried out on Integrated IPS material by taking human activity in fulfilling needs as the sub-topic. This topic is considered so complexthat it needs interesting and contextual learning to make the studentsunderstand it in depth and independently. The implementation of problem-based learning with jigsaw settings was carried out for three meetings with each meeting lasting $2 \times 45$ minutes. The steps for problem-based learning with the Jigsaw setting are as follows:

a. Students are divided into several groups (each group consists of 5-6 people). The so-called 'home group'.

b. Each student in each team gets a different problem.

c. Students with the same problem meet to discuss with the expert groups.

d. After finishing discussing the problem to provide solutions, the experts return to the original group.

e. The experts explain the results of the discussion to the original group.

f. Each group presented the results of the discussion by appointing one member as a group representative.

g. Students take individual quizzes covering all topics..

After the stages of the problem-based learning process with the Jigsaw setting were carried out well, then students were given a learning independence questionnaire. The results of the hypothesis test analysis can be seen in table 3 below

Table 3. Results of the T-Test Analysis for Problem-Based Learning with Jigsaw Settings on the Integrated Social Studies Independent Learning

\begin{tabular}{|c|c|c|c|c|c|c|}
\hline \multicolumn{7}{|c|}{ Coefficients $^{\mathrm{a}}$} \\
\hline & \multirow{2}{*}{ Model } & \multicolumn{2}{|c|}{$\begin{array}{l}\text { Unstandardized } \\
\text { Coefficients }\end{array}$} & \multirow{2}{*}{$\begin{array}{c}\begin{array}{c}\text { Standardized } \\
\text { Coefficients }\end{array} \\
\text { Beta } \\
\end{array}$} & \multirow[t]{2}{*}{$\mathbf{T}$} & \multirow[t]{2}{*}{ Sig. } \\
\hline & & B & Std. Error & & & \\
\hline \multirow{2}{*}{1} & (Constant) & 53.249 & 4.314 & & 12.343 & .000 \\
\hline & $\mathrm{X}$ & -.421 & .381 & -.216 & -1.105 & .280 \\
\hline
\end{tabular}

Based on the results of the t-test analysis in table 3 , the value $(\mathrm{sig})=0.000$. This means $0.000<0.05$, it can be concluded that there is a significant influence between problem-based learning and the Jigsaw setting on the learning independence of Integrated IPS for Junior High 
School Students. In addition, it can also be seen from the average percentage of student independence, where the experimental class is $72 \%$ higher than the control class which is only $60 \%$. The percentage of student independence can be seen in table 4 below.

Table 4. Average Percentage of Integrated IPS Independent Learning

\begin{tabular}{lll}
\hline \multirow{2}{*}{ Class } & \multicolumn{2}{c}{ QuestionnaireData afterTreatment } \\
\cline { 2 - 3 } & \multicolumn{1}{c}{ Average (\%) } & \multicolumn{1}{c}{ Category } \\
\hline Experiment & $72 \%$ & Independent \\
Control & $60 \%$ & Self Sufficient \\
\hline
\end{tabular}

Problem-based learning with a jigsaw setting is very effective in increasing student learning independence as it presents contextual problems at the beginning of learning to provide stimuli and triggers for students to think. Giving stimulus encourages students to be independent in solving problems, so that they are also independent in learning. In line with Sugandi's research (2013) [13], which reports that problem-based learning with the jigsaw cooperative setting greatly affects the students' independent learning ability which has high correlation with student learning success.

Problem-based learning with jigsaw setting also trains students to be responsible for their learning activities, not just being recipients of information but having to find the information needed in learning. It requires students to be active, creative and innovative in seeking information to solve problems. This is in accordance with the demands of independent learning. The increase in learning independence can be influenced by the stages of this learning. The stages of problem-based learning with a jigsaw setting that affect student learning independence are as follows:

a. Student's life is realistic, at this stage, students are given problems in everyday life that can provide stimulation to think about how to solve them independently;

b. The concept is in accordance with student needs, in learning students are faced with various problems that are tailored to the material and daily life, so that students will find out how to solve continuous problems;

c. To develop the nature of student inquiry, at this stage, students are required to think critically and analytically to solve problems independently.

d. The retention of the concept becomes strong, the application of the concept in an effort to solve problems will make students understand the material, not only in the form of memorization;

e. Developing the problem solving ability, the various problems given will increase students' insights through discussions which are carried out together with peers to find solutions to the problems.

The achievement of optimal learning independence cannot be separated from the role of teachers who continue supporting the implementation of this learning properly. The learning meeting was held three times. The teacher always facilitated and encouraged students to solve problems analytically so that students will continue striving to find the best solution of a problem.

Learning independence is indicated by the ability to be able to solve problems faced through behavior. In other words, there are such behavior changes that students have increased thinking as well. They learn to be independent without relying on other people's help and do not only depend on their teachersas they can use various sources and media for learning. In this case, the teacher acts as such a facilitator and consultant that $\mathrm{s} /$ heis not the only source of knowledge [15]. 
There are additional findings in problem-based learning research with a jigsaw setting. First, students become more active. At the problem-based learning stage with the jigsaw cooperative setting, students become active when discussing and solving problems. Students are able to understand the learning material easily because they construct their own knowledge based on the experiences they have experienced. Moreover, students are also able to answer questions or solve problems with contextual and applicable answers. Second, students are trained to think creatively as each student gets a task to solve different problems

\section{Conclusion}

Based on the results and discussion of the research above, it can be concluded that problem-based learning with the jigsaw cooperative setting greatly affects the learning independence of SMP N 1 Bandar Pacitan students. This is evidenced by the results of the $t$ test with a significance value of $0.00<0.05$, so $\mathrm{H} 0$ is rejected. It indicates that there is a significant effect between problem-based learning and the jigsaw cooperative setting towardsthe independent learning of Integrated Social Studies for junior high school students on human activity in fulfilling needs topic. The researchers suggest the readers and other researchers to examine the effect of problem-based learning with jigsaw settings on different variables, different research locations, different education levels, anddifferent materials. Besides, combining the problem-based learning with other learning models is also suggested.

\section{References}

[1] N. Alfiyah and D. Hisyam, "Hubungan antara Kemandirian Belajar dan Lingkungan Belajar dengan Prestasi Belajar Mahasiswa Prodi Pendidikan Administrasi Perkantoran Angkatan 2010 FIS-UNY," Efisiensi - Kaji. Ilmu Adm., vol. 12, no. 1, pp. 53-66, 2015, doi: 10.21831 /efisiensi.v12i1.3866.

[2] U. Sumarmo, "Kemandirian Belajar: Apa, Mengapa, dan Bagaimana dikembangkan pada Peserta Didik," 2002.

[3] H. Suhendri, "Pengaruh Metode Pembelajaran Problem Solving terhadap Hasil Belajar Matematika Ditinjau dari Kemandirian Belajar," Form. J. Ilm. Pendidik. MIPA, vol. 3, no. 2, pp. 105-114, 2015, doi: 10.30998/formatif.v3i2.117.

[4] Nuraeni, S. D. Fatmaryanti, and Ashari, "Peningkatan Kemandirian Belajar IPA melalui Pembelajaran Kooperatif Tipe Group Investigation ( GI ) di Kelas VIII SMP Negeri 33 Purworejo Tahun Pelajaran 2011 / 2012," RADIASI J. Berk. Pendidik. Fis., vol. 1, no. 1, pp. 15-18, 2012, [Online]. Available: http://ejournal.umpwr.ac.id/index.php/radiasi/article/view/233.

[5] R. Purwasih, "Peningkatan Kemandirian Belajar Mahasiswa Melalui Pembelajaran Personalized System Of Instruction," 2016.

[6] "Peraturan Menteri Pendidikan dan Kebudayaan Republik Indonesia Nomor 68 Tentang Kerangka Dasar dan Struktur Kurikulum di Sekolah Menegah Pertama / Madrasah Tsanawiyah.” 2013.

[7] Nurdyansyah and E. F. Fahyuni, Inovasi Model Model Pembelajaran. 2016.

[8] O. P. Afandi, Muhamad; Chamalah, Evi; Wardani, Model Dan Metode Pembelajaran di Sekolah. Semarang: Unissula Press, 2013.

[9] Trianto, Model-Model Pembelajaran Inovativ Berorentasi Kontuktivistik. Jakarta: 
Bumi Aksara, 2010.

[10] M. S. Humaisi, Pengantar Ilmu Pengetahuan Sosial. STAIN Ponorogo Press, 2012.

[11] Fahinu, "Meningkatkan Kemampuan Berpikir Kritis dan Kemandirian Belajar Matematik pada Mahasiswa melalui Pembelajaran Generatif," Universitas Pendidikan Indonesia, 2007.

[12] E. E. A.M, Budiyanto; Rohaeti, "Pembelajaran berbasis masalah," J. Pendidik. Mat., vol. 1, no. 1, pp. 1-6, 2012.

[13] A. I. Sugandi, "Pengaruh Pembelajaran Berbasis Masalah Dengan Setting Kooperatif Jigsaw Terhadap Kemandirian Belajar Siswa Sma,” Infin. J., vol. 2, no. 2, p. 144, 2013, doi: 10.22460/infinity.v2i2.31.

[14] Sugiyono, Metode Penelitian Pendidikan Kuantitatif, Kualitatif, dan R\&D. Bandung: Alfabeta, 2018.

[15] S. Yanti and E. Surya, "Kemandirian Belajar dalam Memaksimalkan Kualitas Pembelajaran," Artik. Penelit., pp. 1-10, 2017. 